\title{
Thermal analysis of the combustion chamber of an industrial hot water spray washing machine
}

\author{
Ashimedua Ogochukwu Godwin ${ }^{1}$, Enibe Samuel Ogbonna ${ }^{2}$, Kebodi Chiedu Lawrence ${ }^{1}$ \\ ${ }^{1}$ Mechanical Engineering Technology Dept., Delta State Polytechnic, Ogwashi-Uku, Nigeria \\ ${ }^{2}$ Mechanical Engineering Dept., University of Nigeria, Nsukka, Nigeria
}

Email address:

godwin.ashimedua@yahoo.com(Ashimedua O. G.)

\section{To cite this article:}

Ashimedua Ogochukwu Godwin, Enibe Samuel Ogbonna, Kebodi Chiedu Lawrence. Thermal Analysis of the Combustion Chamber of an Industrial Hot Water Spray Washing Machine. International Journal of Energy and Power Engineering. Vol. 3, No. 6, 2014 , pp. $323-330$. doi: $10.11648 /$ j.ijepe. 20140306.15

\begin{abstract}
The thermal analysis of an industrial hot water spray washing machine using hot air from the combustion of diesel fuel to heat up water that flows through a spirally coiled steel tube heat exchanger inside a steel shell combustion chamber was analyzed. The working fluids used are water and air. The spirally coiled tube is made by bending a $15 \mathrm{~mm}$ diameter and $3 \mathrm{~mm}$ thick straight pipe into 4 turns and 9 layers respectively. The total length of the tube is approximately $20 \mathrm{~m}$. Water at ambient temperature flows into the coil through the outermost turn and flows out through the innermost turn. The adiabatic flame temperature of the fuel was determined. The in-tube and the outside convective heat transfer coefficients were determined using the appropriate correlations available in literature. A mathematical model of the heat transferred to the water was formulated and solved using the Engineering Equation Solver (EES). The results obtained are in reasonable agreement with measured data. Parametric study was done to determine the effects of each parameter on the outlet water temperature.
\end{abstract}

Keywords: Stoichiometric, Adiabatic Flame Temperature, Convective Heat Transfer Coefficient

\section{Introduction}

The need for cleaning of household items, automobile parts, industrial equipment, and other surfaces has given birth to the design and construction of various cleaning devices. These devices have various sizes depending on design and power rating. The smaller ones are mainly used for cleaning of household items, while the bigger ones are used for cleaning of industrial equipment. Apart from the purpose of aesthetics and hygiene, cleaning is a requisite condition for proper functioning of many machine components. A heat transfer device, for instance, will not perform very efficiently due to the effect of fouling (i.e. the accumulation of scaly deposits on the surface of the device) if not regularly cleaned either chemically or mechanically. For example, a clogged radiator is one of the causes of automobile engine overheating. Hence, the importance of cleaning cannot be overemphasized.

Industrial spray washing machine is one of the various devices used for cleaning. They come in two categories: the hot and the cold water types. The hot water type uses sprays of highly pressurized hot water and washing agents such as detergents to clean surfaces. It can be used to clean up oil, grease, mud, dust particles, etc. It is also ideal for flushing away deposits and preparing surfaces for painting. The deviceis shown in Fig. 1 below and its basic components and their functions are listed in Table 1.

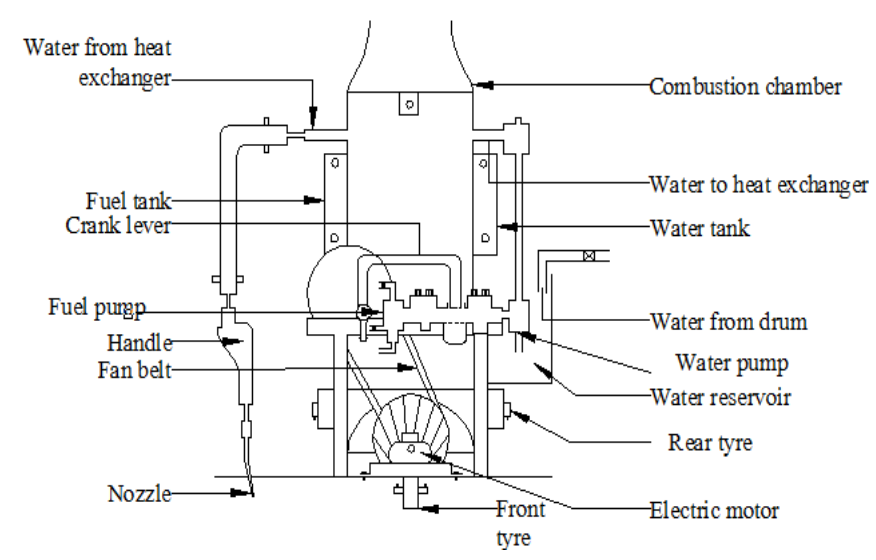

Fig. 1. Front view of the machine. 
Table 1. Components and Their Functions.

\begin{tabular}{|c|c|}
\hline Component & Function \\
\hline A fuel tank & The fuel tank contains the fuel used in the combustion process. \\
\hline A water tank & The water tank contains the water that is used for the washing. \\
\hline $\begin{array}{l}\text { Two double acting } \\
\text { reciprocating pumps }\end{array}$ & The pumps are used to pressurize the fuel and the water respectively. \\
\hline The suction lines & The suction lines allow fuel and water to flow to the pumps. \\
\hline The discharge lines & $\begin{array}{l}\text { The discharge lines allow the fuel to flow to the combustion chamber and the water to flow through the spirally coiled steel } \\
\text { tube compact heat exchanger in the combustion chamber, the pressure hose and the nozzle to the outside }\end{array}$ \\
\hline $\begin{array}{l}\text { A spirally coiled steel tube } \\
\text { compact heat exchanger }\end{array}$ & $\begin{array}{l}\text { The spirally coiled steel tube compact heat exchanger is a heat transfer surface through which the heat generated in the } \\
\text { combustion chamber is transferred to the water. }\end{array}$ \\
\hline A mobile chassis & The mobile chassis allows for mobility of the machine. The super structure is mounted on the chassis. \\
\hline A pressure hose with a nozzle & $\begin{array}{l}\text { A pressure hose is used so that it can withstand the water outlet pressure, while the nozzle helps to increase the velocity of } \\
\text { water spray. }\end{array}$ \\
\hline An electric motor & $\begin{array}{l}\text { The electric motor provides the driving force for the system. The electric motor is energized by either an electric source or a } \\
\text { generator. }\end{array}$ \\
\hline A fan and housing & The fan allows air and flame to be properly distributed in the combustion chamber. It is protected by the housing. \\
\hline $\begin{array}{l}\text { A combustion chamber } \\
\text { A pulley system }\end{array}$ & $\begin{array}{l}\text { The combustion chamber is the chamber where the hydrocarbon (fuel) burns to generate the heat used to heat up the water. } \\
\text { It helps to drive the fuel and water pumps and the fan. }\end{array}$ \\
\hline
\end{tabular}

\subsection{How the Machine Works}

By energizing the electric motor, which drives the fuel and the water pumps through a pulley system and crank and slide mechanism, the fuel from the tank flows through the suction line of a high-pressure fuel pump which increases its pressure as it enters the combustion chamber. Then, the fuel is ignited and heat is generated from the combustion process. The flame is made steady and relatively uniform by the air blown into the chamber by the fan for effective heat transfer into the water in the coil. At the same time too, water from the tank enters the suction pipe of a high-pressure water pump, which speeds the water on its way through the heat exchanger, consisting of four turns and nine layers of spirally coiled steel tube. The spiral winding configuration allows the water to get maximum exposure to the flame (fuelled by diesel) as it flows through the centre of the coil. By the time the water rushes out of the coil and through a smaller diameter pressure-hose and a nozzle, the pressure and temperature would have risen. Then, the hot water which is very energetic and contains a washing agent (detergent) can easily penetrate the particles of grease and grime very easily.

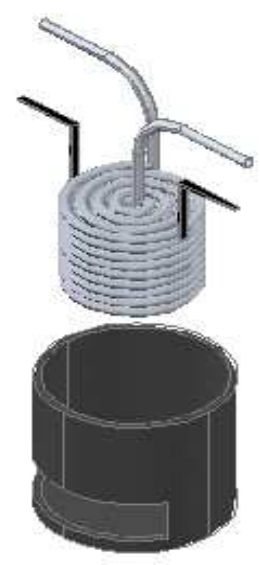

Fig. 2.the coiled tube and the shell.
The work is on the combustion chamber, which is made up of the spirally coiled steel tube enclosed in a steel shell. The spiral coil tube is shown in Fig. 2. Due to the curvature of the tube, a centrifugal force is generated as fluid flows through curved tubes. A secondary flow induced by the centrifugal force has significant ability to enhance the heat transfer rate. The spiral coil tubes are used in so many applications because of its compact nature and its high heat transfer coefficient. It has been successfully used in refrigeration and air conditioning systems, oil extraction systems, food and diary industries, and heat recovery processes, as in this very study. Heat transfer and fluid flow behaviours in spiral tubes have been studied by a number of researchers.

Naphon and Wongwises[1] did a review of flow and heat transfer characteristics in curved tubes. In the work, they presented the average in-tube heat transfer coefficient in spirally coiled tubes as proposed in their earlier work on experimental study on the in-tube convective heat transfer coefficients in a spiral-coil heat exchanger.

Naphon and Wongwises[2] experimentally investigated the average tube-side and air-side heat transfer coefficients in a spirally coiled finned tube heat exchanger under dry- and wet-surface conditions. In the work, they proposed new correlations based on the data gathered during the work for predicting the tube-side and air-side heat transfer coefficients for the spirally coiled finned tube heat exchanger.

Naphon and Wongwises [3], in their work on the heat transfer characteristics of a compact spiral coil heat exchanger under wet-surface conditions, investigated the heat transfer characteristics and performance of a spiral coil heat exchanger under cooling and dehumidifying conditions. The data obtained from the new model they developed were in reasonable agreement with measured experimental data.

Wongwises and Naphon [4] experimentally and theoretically studied the heat transfer characteristics and performance of a spirally coiled heat exchanger under sensible cooling conditions.

Yoo et al [5] investigated in details the effects of Reynolds 
number and curvature ratio on fluid flow and heat transfer characteristics of spiral coiled tube. They performed their analyses to find velocity distribution, pressure drop and heat transfer with different Reynolds number and curvature ratios and presented their physical significances. Individual effects of Reynolds number and curvature ratio on the flow were also assessed.

Kondhalkar and Kapatkat [6] did performance analysis of spiral tube heat exchanger used in oil extraction system. Their study showed that the use of spirally coiled tube heat exchanger significantly improved the overall heat transfer coefficient. The paper also showed that the spiral coil tube saved cost, reduced the effects of fouling due to the scrubbing effects of fluid as it passes through the tube and reduced oil sticking problem usually encountered in straight tubes, thereby increasing productivity.

In open literature, there are few researches on the heat transfer and flow characteristics in spirally coiled tubes compared to the numerous investigations in helically coiled tubes; and these researches are mainly on low temperature processes. In this study, the heat transfer characteristics and performance of the spirally coiled heat exchanger under dry-surface conditions using hot air from the combustion of diesel fuel was studied.

\section{Problem Statement}

Steam washing machines employ three elements in its operations. They include heat, agitation, and cleaning agent (detergent). The need to determine the heat transfer characteristics and performance of the spirally coiled tube placed in the combustion chamber gave rise to the problem, which is to analyse the heat transfer processes in the system.

\section{Purpose and Significance of Study}

The study is exploratory in nature as it seeks to thermally analyse the system by determining: (a) the adiabatic flame temperature of the fuel, (b) the in-tube and the outside convective heat transfer coefficients using the appropriate correlations; and use data generated from (a) and (b) to determine the outlet temperature of the water-detergent mixture using the heat transfer mathematical model formulated from of the system. The result from the research will guide engineers who may want to manufacture the system locally here. It will also open window for further studies geared towards the improvement of its performance.

\subsection{Applications of the Machine}

Hot water pressure washers have been found to be useful in various cleaning projects, domestically and industrially. The areas where it can be applied include all or some of the following:

1. Cleaning automobile parts and engines,

2. Cleaning of heavy industrial machinery,

3. Cleaning of surfaces before painting,

4. Flushing of refrigerator parts, e.g. condenser,
5. Cleaning of automobile mechanic workshop floors,

6. Cleaning of walk ways in engine rooms of flow stations, etc.

\subsection{Economic Relevance of the Machine}

The machine has the following economic relevance:

1. The machine creates employment for the operators.

2. The quality of the washing is better than that of manual washing.

3. It reduces the man hour lost during manual washing.

4. It increases the earning power of the operators.

5. The use of the machine saves money in buying detergent since less detergent is needed as the water is pushed through the machine at such a powerful rate.

\section{Materials and Methods}

\subsection{Assumptions}

The following assumptions were made in the analysis:

- The combustion gases are ideal.

- The combustion is complete.

- There is no dissociation of the products of combustion.

- Flows of air and water are steady.

- There is no heat loss between system and surroundings.

- The thermal resistance of the liquid film is neglected.

- Each completed coil turn is approximately circular.

- The thermal conductivity of the spirally coiled tube is constant.

- The heat generated in the chamber is steady.

- The detergent does not affect the properties of water as its quantity is negligibly small relative to the volume of the water.

\subsection{The Dimensions of the Spirally Coiled Tube Heat Exchanger}

Dimensions of the spirally coiled tube heat exchanger currently under investigation are shown in Table 2.

Table 2. Dimensions of the spirally coiled tube heat exchanger.

\begin{tabular}{ll}
\hline Outer diameter of tube $\left(d_{o}\right), \mathrm{mm}$ & 15 \\
Inner diameter of tube $\left(d_{i}\right), \mathrm{mm}$ & 9 \\
Internal radius of curvature $\left(R_{i}\right), \mathrm{mm}$ & 112 \\
Number of coil turns & 4 \\
Number of spiral coils (layers) & 9 \\
Distance between spiral coil turns $\left(X_{t}-d_{o}\right), \mathrm{mm}$ & 18 \\
Diameter of shell, mm & 270 \\
Height of shell, mm & 610 \\
\hline
\end{tabular}

\subsection{Review of the Processes Involved in the Analysis}

This section of the work considered the combustion process, the heat transfer process, and the flow characteristics of the working fluid (water) in the heat exchanger. The whole of the three processes are interconnected. The combustion process provides the heat energy (chemical energy), which is transferred to the working fluid (water), under the influence of 
an external entity, the water pump. Hence, the mode of heat transfer dominant in the tube is forced convection.

Two basic laws were applied in the combustion process analysis. They include the law of conservation of mass (mass balance) and the law of conservation of energy (energy balance). Mass conservation requires that the total mass of each element is conserved during a chemical reaction. This mass analysis was used to evaluate the air-fuel ratio and the mass of each constituent $\left(m_{i}\right)$, which was used to determine the adiabatic flame temperature. The fuel used is diesel fuel, which for convenience, will be treated as dodecane, $\mathrm{C}_{12} \mathrm{H}_{26}$ since it is the most dominant compound in diesel fuel. The first law of thermodynamics was applied in the energy balance analysis.

\subsection{The Mass Balance}

The stoichiometric equation for the reaction is given below

$$
\mathrm{C}_{12} \mathrm{H}_{26}+\mathrm{a}\left(0.21 \mathrm{O}_{2}+0.79 \mathrm{~N}_{2}\right) \rightarrow \mathrm{bCO}_{2}+\mathrm{cH}_{2} \mathrm{O}+0.79 \mathrm{aN}_{2}
$$

where the coefficients $\mathrm{a}, \mathrm{b}$, and $\mathrm{c}$ are found to be $88.1,12$, and 13 respectively, by performing atomic balance for each constituent element.

Substituting the values $\mathrm{a}, \mathrm{b}$, and $\mathrm{c}$ into the above chemical equation, gives

$$
\mathrm{C}_{12} \mathrm{H}_{26}+88.1\left(0.21 \mathrm{O}_{2}+0.79 \mathrm{~N}_{2}\right) \rightarrow 12 \mathrm{CO}_{2}+13 \mathrm{H}_{2} \mathrm{O}+0.79(88.1) \mathrm{N}_{2}
$$

$\mathrm{Or}$

$$
\mathrm{C}_{12} \mathrm{H}_{26}+18.5 \mathrm{O}_{2}+69.599 \mathrm{~N}_{2} \rightarrow 12 \mathrm{CO}_{2}+13 \mathrm{H}_{2} \mathrm{O}+69.599 \mathrm{~N}_{2}
$$

The above chemical equation was used to determine the air-fuel ratio as $14.95 \mathrm{~kg}_{a} / \mathrm{kg}_{f}$, as well as the mass of each constituent $\left(m_{i}\right)$. This air-fuel ratio $\left(14.95 \mathrm{~kg}_{a} / \mathrm{kg}_{f}\right)$ is the stoichiometric or theoretical air required for the complete combustion of $1 \mathrm{~kg}$ of dodecane $\left(\mathrm{C}_{12} \mathrm{H}_{26}\right)$.

\subsection{Adiabatic Flame Temperature Determination}

The enthalpy of combustion $\left(\overline{h_{c}}\right)$ of diesel (Dodecane, $\mathrm{C}_{12} \mathrm{H}_{26}$ ) at $25^{\circ} \mathrm{C}$ and $1 \mathrm{~atm}$ can be calculated using the enthalpy of formation data from Boles and Cengel [36]. It is assumed that the water in the product is in gaseous form.

$$
\bar{h}_{c}=\bar{h}_{\text {prod }}-\bar{h}_{\text {react }}
$$

From eq. (1), the enthalpy of combustion for this reaction is given as

$$
\bar{h}_{c}=\sum N p \bar{h}_{f}^{o},{ }_{p}-\sum N r \bar{h}_{f}^{o},_{r}=\left(N\left(\bar{h}_{f}^{o}\right)_{C_{2}}+\left(N \bar{h}_{f}^{o}\right)_{H_{2} 0}-\left(N \bar{h}_{f}^{o}\right)_{C_{12} H_{26}}\right.
$$

From the above expression, the enthalpy of combustion for $1 \mathrm{~kg}$ of $\mathrm{C}_{12} \mathrm{H}_{26}$ is $-44558 \mathrm{~kJ} / \mathrm{kg}$. This value is also the lower heating value of dodecane since the water in the product is assumed to be in the gaseous form.

From the steady flow energy equation for a system delivering no useful work with negligible kinetic and potential energy, the heat released is given by

$$
Q=H_{P_{2}}-H_{R_{1}}
$$

where $H_{P_{2}}$ is the final enthalpy of the products and $H_{P_{1}}$ is the initial enthalpy of the reactants.

Eq. (2) can be expanded for an adiabatic condition as follows

$$
Q=\left(H_{P_{2}}-H_{P_{0}}\right)+\Delta H_{0}+\left(H_{R_{0}}-H_{R_{I}}\right)=0
$$

where $\Delta H_{0}=H_{P_{0}}-H_{R_{0}}$ is the enthalpy of combustion of dodecane at the reference state.

Eq. (3) can further be expanded for an ideal gas as follows

$$
\sum_{P} m_{i} C_{p i}\left(T_{2}-T_{0}\right)+\Delta H_{0}+\sum_{R} m_{i} C_{p i}\left(T_{0}-T_{1}\right)=0
$$

where $m_{i}$ is mass of each constituent, $C_{p i}$ is the specific heat capacity of each constituent, $T_{o}$ is the reference temperature, $T_{1}$ is the initial temperature of reactants and $T_{2}$ is the final temperature of products.

This equation was used iteratively to determine the final temperature of the combustion process $\left(T_{2}\right)$, as $2094^{\circ} \mathrm{C}$, which is the adiabatic flame temperature of this combustion process. The adiabatic flame temperature is the final temperature of a combustion mixture assuming that no heat is lost to the surroundings and that there is no dissociation of the products of combustion, Boles and Cengel [36].

\subsection{Determination of the in-tube Convective Heat Transfer Coefficient}

Naphon and Wongwises [19] presented a Nussult number $\left(N_{u}\right)$ correlationthat could be used to deduce the in-tube convective heat transfer coefficient $\left(h_{i}\right)$ of spirally coiled tube as

$$
N_{u}=\frac{h_{i} d_{i}}{k}=5.38 D_{e}^{0.287} P_{r}^{-0.949}
$$

for $300 \leq D_{e} \leq 2200, P_{r} \geq 5$

where Dean number, $D_{e}=2 R_{e} \sqrt{r_{h} R_{i} e^{a \theta}}, R_{e}$ is Reynolds number, $r_{h}$ is the hydraulic radius, $R_{i}$ is the internal radius of curvature, $a$ is a constant taken as 0.05 , Yoo et al [5], and $\theta$ is the total angle turned through, given in this work as $8 \pi$ (four turns).

\subsection{Determination of the Air-side Convective Heat Transfer Coefficient}

Naphon and Wongwises [19] predicted that the air-side convective heat transfer coefficient $\left(h_{o}\right)$ for a spirally coiled tube under dry surface conditions could be deduced from the Colburn $\mathrm{j}$ factor correlation given as

$$
J=\frac{h_{o}}{G_{\max } C_{p, a}} P_{r}^{2 / 3}=0.133 R_{e o}^{-0.376}
$$


For $R_{e o}<6000$

\subsection{Heat Transfer in Terms of the Overall Heat Transfer Coefficient}

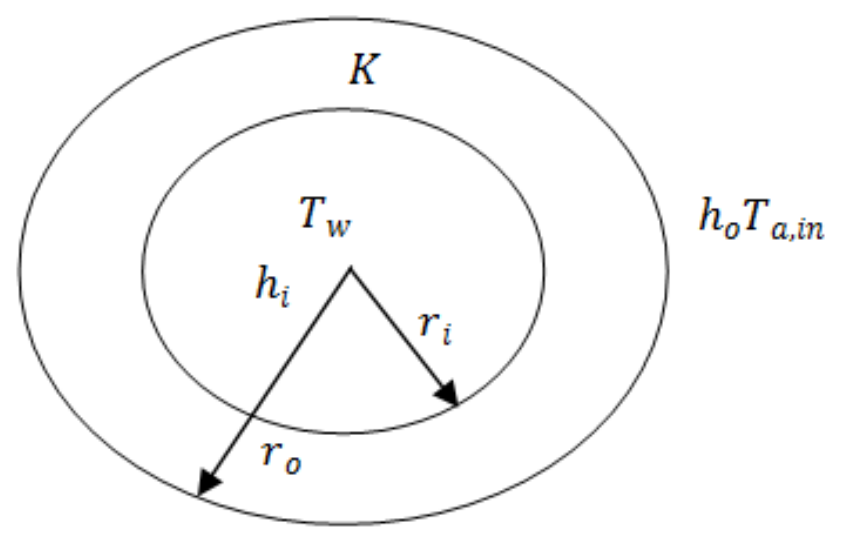

Fig. 3.Tube cross-section.

The heat transferred per unit length of the pipe into the water can be written as

$$
Q=U_{o} 2 \pi r_{o}\left(T_{a, i n}-T_{w}\right)
$$

where $U_{o}=\frac{1}{\frac{1}{h_{o}}+\frac{r_{o} t}{K r_{m}}+\frac{r_{o}}{h_{i} r_{i}}}$

$U_{o}$ is the overall heat transfer coefficient based on the outside surface radius, $T_{a, i n}$ is the inlet air temperature, $T_{w}$ is the temperature of water, $r_{m}$ is the $\log -$ mean radius of the pipe, $t$ is the thickness of the pipe, $h_{o}$ is the air-side heat transfer coefficient, $h_{i}$ is the water-side heat transfer coefficient and $r_{i}$ and $r_{o}$ are the inside and outside radii of the pipe.

$$
\begin{gathered}
r_{m}=\frac{r_{o}-r_{i}}{\ln \left(r_{o} / r_{i}\right)} \\
t=r_{o}-r_{i}
\end{gathered}
$$

4.9. Heat Transfer in Terms of the Water Mass Flow Rate

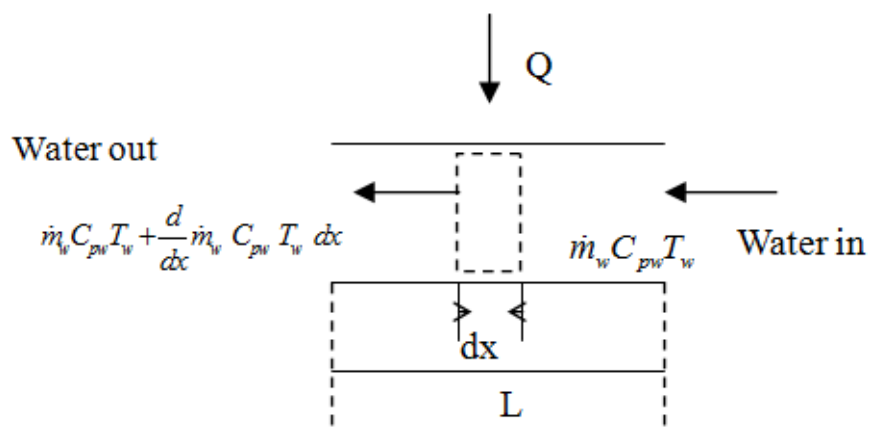

Fig. 4. Control volume showing how heat flows into the water in the tube.

If $\mathrm{Q}$ is the heat transferred into the water per unit length of the pipe, applying the first law to the control volume of length, dx as shown in Fig. 4 above, we get

$$
\dot{m}_{w} C_{p w} T_{w}-\left(\dot{m}_{w} C_{p w} T_{w}+\frac{d}{d x} \dot{m}_{w} C_{p w} T_{w} d x\right)+Q d x=0
$$

Simplifying the above equation, gives

$$
Q=\dot{m}_{w} C_{p w} \frac{d T_{w}}{d x}
$$

Equation 7 shows the expression for the heat flow per unit length of the pipe into the water.

But the total heat absorbed by the water is

$$
Q_{w}=\dot{m}_{w} C_{p, w}\left(T_{w, o u t}-T_{w, \text { in }}\right)
$$

\subsection{Energy Balance}

Equating eq. (4) to eq. (7), gives

$$
\frac{d T_{w}}{d x}=\frac{2 \pi r_{o} U_{o}}{\dot{m}_{w} C_{p w}}\left(T_{a, i n}-T_{w}\right)
$$

Multiplying both sides by -1 , gives

$$
\frac{-d T_{w}}{d x}=\frac{2 \pi r_{o} U_{o}}{\dot{m}_{w} C_{p w}}\left(T_{w}-T_{a, i n}\right)
$$

Separating variables, gives

$$
\frac{d T_{w}}{\left(T_{w}-T_{a, \text { in }}\right)}=\frac{-2 \pi r_{o} U_{o}}{\dot{m}_{w} C_{p w}} d x
$$

Integrating eq.(11), gives

$$
\ln \left(T_{w}-T_{a, i n}\right)=\frac{-2 \pi r_{o} U_{o}}{\dot{m}_{w} C_{p w}} x+C
$$

Taking the exponential of both sides, gives

$$
\begin{gathered}
T_{w}-T_{a, i n}=\ell^{\frac{-2 \pi r_{o} U_{o}}{\dot{m}_{w} C_{p w}} x+C}=C^{\prime} \ell^{\frac{-2 \pi r_{o} U_{o}}{\dot{m}_{w} C_{p w}} x} \\
\therefore T_{w}-T_{a, \text { in }}=C^{\prime} \ell^{\frac{-2 \pi r_{o} U_{o}}{\dot{m}_{w} C_{p w}} x}
\end{gathered}
$$

where $\mathrm{C}^{\prime}$ is a constant that is determined from the boundary condition that at $\mathrm{x}=0, \mathrm{~T}_{\mathrm{w}}=\mathrm{T}_{\mathrm{w}, \text { in }}$

$$
\therefore C^{\prime}=\mathrm{T}_{\mathrm{w}, \text { in }}-\mathrm{T}_{\mathrm{a}, \text { in }}
$$

Substituting eq.(13) into eq.(12), gives

$$
\frac{T_{w}-T_{a, i n}}{T_{w, i n}-T_{a, i n}}=\ell^{\frac{-2 \pi r_{o} U_{o} x}{\dot{m}_{w} C_{p w}}}
$$

Eq. 14 shows the water temperature dependence on the pipe length, x. With Eq.(14), the outlet water temperature can be calculated at $\mathrm{x}=\mathrm{L}$ from: 


$$
\begin{aligned}
& \frac{T_{w, \text { out }}-T_{a, \text { in }}}{T_{w, \text { in }}-T_{a, \text { in }}}=\ell^{\frac{-2 \pi r_{o} U_{o} L}{\dot{m}_{w} C_{p w}}} \\
\therefore & \frac{T_{w, \text { out }}-T_{a, \text { in }}}{T_{w, \text { in }}-T_{a, \text { in }}}=\ell^{\frac{-A_{o} U_{o}}{\dot{m}_{w} C_{p w}}}
\end{aligned}
$$

where $A_{o}=9\left(2 \pi r_{o} L\right)$

and $L=2 \pi \sum_{i=1}^{4} R_{n}$

Eq. (16) can be simplified as

$$
\mathrm{T}_{\mathrm{w}, \text { out }}=\mathrm{yT}_{\mathrm{w}, \text { in }}+(1-\mathrm{y}) \mathrm{T}_{\mathrm{a}, \text { in }}
$$

where $\mathrm{y}=\ell^{\frac{-A_{o} U_{o}}{\dot{m}_{w} C_{p w}}}$

\subsection{Solution Method}

In order to solve the model, the relevant water-side and air-side heat transfer coefficients are needed. These are determinedusing eq. (4) and eq. (5). The heat exchanger configuration, the properties of the working fluids and the operating conditions are also needed. Eq. (17) is solved to determine the water outlet temperature, $T_{w, o u t}$. The value obtained is substituted into eq. (8) to determine the heat transferred into the water.

\section{Model's Performance}

The model was solved using the Engineering Equation Solver (EES) and a number of plots were made, varying two parameters while keeping the other constant. The following plots were obtained forthe spiral-coiled steel tube material.

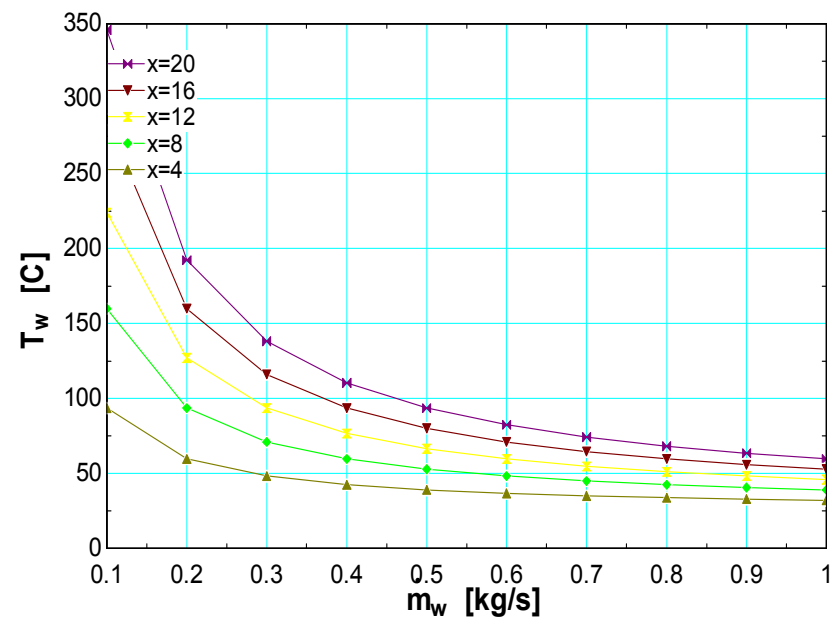

Fig. 5. Variation of outlet water temperature with water mass flow rate for different pipe lengths.

Fig. 5 shows the variation of outlet-water temperature with water mass flow rate obtained from the model for different pipe lengths of $4,8,12,16$ and $20 \mathrm{~m}$. At an inlet-air temperature of $2094^{\circ} \mathrm{Cand}$ inlet-water temperature of $25^{\circ} \mathrm{C}$, the outlet water temperature tends to decrease as the water mass flow rates increase. It can also be deduced from the same figure that the outlet water temperature increases as the water flow rate decreases and increases as the pipe length increases.

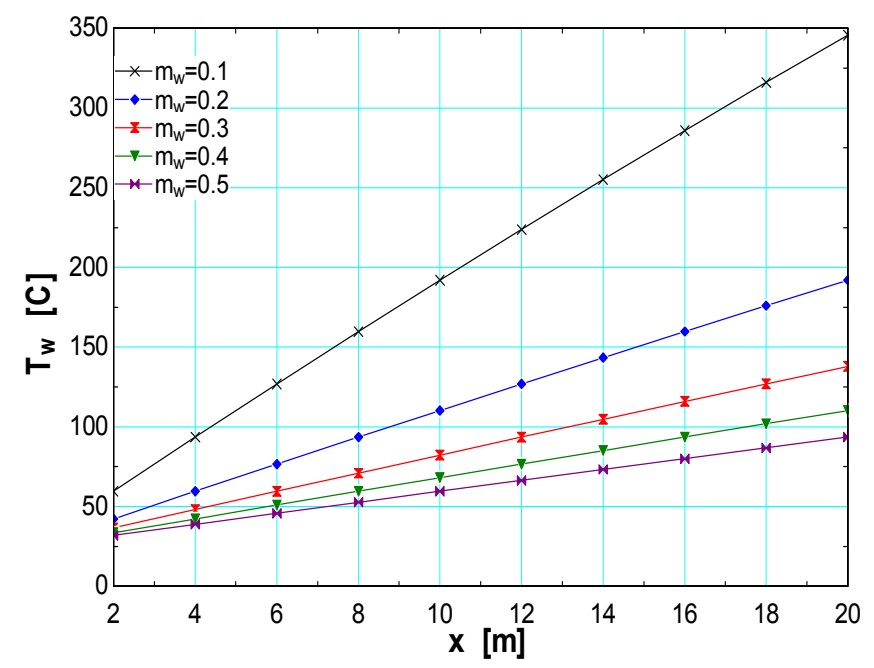

Fig. 6. Variation of outlet water temperature with pipe length for different water mass flow rates.

Fig. 6 shows the variation of the outlet water temperature with pipe length for different water mass flow rates of $0.1,0.2$, $0.3,0.4$ and $0.5 \mathrm{~kg} / \mathrm{s}$ with a pipe of $15 \mathrm{~mm}$ external diameter. At the same inlet-air temperature of $2094^{\circ} \mathrm{C}$ and inlet-water temperature of $25^{\circ} \mathrm{C}$, the outlet-water temperature increases with pipe length because there is sufficient time for heat transfer to take place.

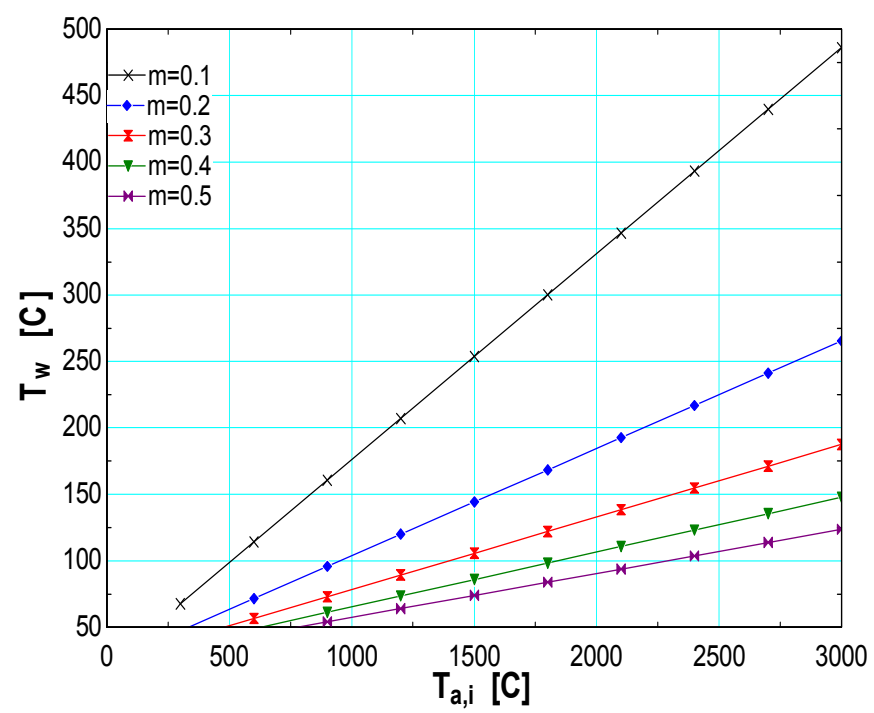

Fig. 7.Variation of the outlet water temperature with the nominal temperature for different mass flow rates of water.

Fig. 7 shows the variation of the outlet water temperature with the inlet-air temperature for various water mass flow rates. It shows that increase in inlet-air temperature will lead to increase in the outlet water temperature.

Fig. 8 shows the variation of the outlet temperature of water with the external pipe radius at different mass flow rates of 
water for a pipe of $20 \mathrm{~m}$ length. It shows that the outlet temperature of water increases as the external pipe radius increases. This is only true when $d_{o}>X_{t}$

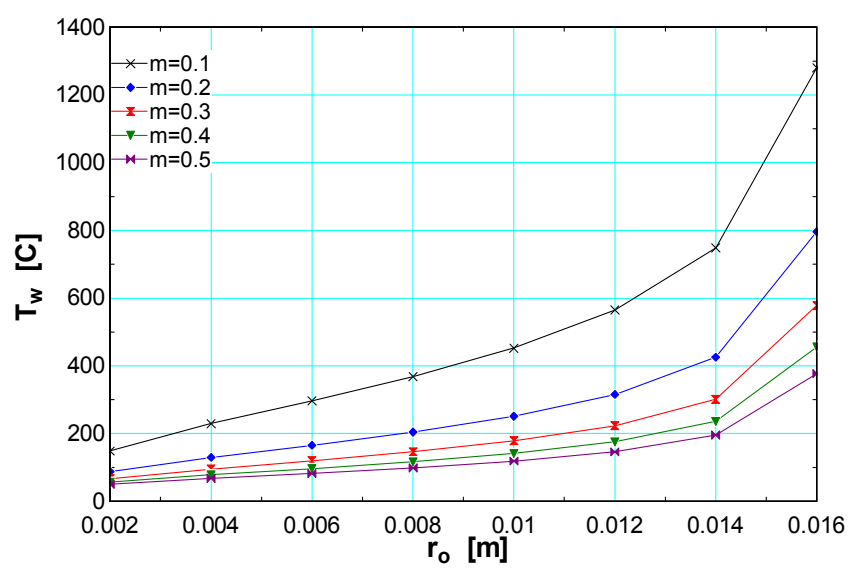

Fig. 8. Variation of water outlet temperature with the external radius of the pipe at various water mass flowrates.

The use of compact heat exchanger is very important because it helps to increase the heat transfer surface. Another benefit is the compactness of the system, which makes a large number of turns to be contained in a small space. The addition of heat to the water together with the pressure and detergent makes the braking of bonds within dirt much easier. What the cold water washer can do, the hot water washer can do much better. Therefore, the hot water spray washing machine is preferred to the cold water pressure washer.

\section{Conclusion}

A model for the heat transfer characteristics and performance of a spiral coil heat exchanger under dry-surface conditions using hot air from the combustion chamber was developed and solved. The results obtained from the developed model agreed with experimental data. The effects of the inlet conditions of the working fluids (air and water) were examined and the following were deduced from the results obtained:

1. The outlet water temperatures decrease with increasing water mass flow rate.

2. The outlet water temperatures increase with increasing pipe length.

3. The nominal flame temperature has a significant effect on increasing the outlet water temperature.

4. The outlet water temperature increases with increasing overall heat transfer coefficient.

5. The outlet water temperature increases with the pipe radius provided that $d_{o}>X_{t}$

Table 3 shows the summary of the results for the device studied. The variation in the result (outlet water temperature, $\left.T_{w, \text { out }}\right)$ of analysis and experimentis due to the inherent heat losses in the device. The final temperature of the water could be significantly increased by insulating the combustion chamber with good fire resistant insulating material.
Table 3. Results from the analysis and the experiment

\begin{tabular}{llll}
\hline Results & Pipe length $[\mathbf{m}]$ & $\dot{\boldsymbol{m}}_{\boldsymbol{w}}[\mathbf{k g} / \mathbf{s}]$ & $\mathbf{T}_{\mathrm{w}, \text { out }}\left[{ }^{\circ} \mathrm{C}\right]($ Steel Tube) \\
\hline Analysis & 20 & 0.2 & 196 \\
Experiment & 20 & 0.2 & 76.5 \\
\hline
\end{tabular}

\section{Nomenclature}

A Area, $m^{2}$

$C_{p}$ Specific heat, $\mathrm{kJ} / \mathrm{kgK}$

$d$ Tube diameter, $m$

$D_{e}$ Dean number

$G$ Mass flux $\left(\mathrm{kg} / \mathrm{m}^{2} \mathrm{~s}\right)$

$h$ Heat transfer coefficient, $W / m^{2}{ }^{\circ} \mathrm{C}$

$J$ Colburn $\mathrm{j}$ factor

$k$ Thermal conductivity, $W / m^{\circ} \mathrm{C}$

$m_{i}$ Mass of each constituent, $\mathrm{kg}$

$\dot{m}$ Mass flow rate, $\mathrm{kg} / \mathrm{s}$

$N_{u}$ Nussult number

$P_{r}$ Prandtl number

$Q$ Heat transfer rate per unit length of pipe, $W / m$

$R$ Coil radius, $m$

$r$ Tube radius, $m$

$R_{e}$ Reynolds number

$T$ Temperature, ${ }^{\circ} \mathrm{C}$

$t$ Thickness, $m$

$U$ Overall heat transfer coefficient, $W / \mathrm{m}^{2 \circ} \mathrm{C}$

$X_{t}$ Transversal spacing of two consecutive rows

$\rho$ Density, $\mathrm{kg} / \mathrm{m}^{3}$

$\mu$ Dynamic viscosity

\section{Subscripts}

a air

f fuel

i inside, constituents

in inlet

$\mathrm{n}$ number of coil turn

o outside

out outlet

st steel( carbon steel, 1\% C)

tot total

w water

\section{References}

[1] Naphon, P. and Wongwises, S.,A review of flow and heat transfer characteristics in curved tubes, Renewable and Sustainable Energy Reviews, 10: 463 - 490, 2006.

[2] Naphon, P. and Wongwises, S., Heat transfer coefficients under dry-and wet-surface conditions for a spirally coiled finned tube heat exchanger, Fluid Mechanics, Thermal Eng and Multiphase Flow Research Lab. (FUTURE), 2004.

[3] Naphon, P. and Wongwises, S., Astudy of the heat transfer characteristics of a compact spiral coil heat exchanger under wet-surface conditions, Experimental Thermal and Fluid Science, 29: 511 - 521, 2005. 
[4] Naphon, P. and Wongwises, S., Heat transfer characteristics and performance of a spirally coiled heat exchanger under sensible cooling conditions, JSME International Journal, 48(4): $810-819,2005$.

[5] Yoo G., Choi H., and Dong W., Fluid flow and heat transfer characteristics of spiral coiled tube: effects of Reynolds number and curvature ratio, J. Central South University, 19: $471-476,2012$

[6] Kondhalkar, G. E. and Kapatkat, V. N., Performance analysis of spiral tube heat exchanger used in oil extraction system, International Journal of Modern Engineering(IJMER), 2: 930 936, 2012.

[7] Holman, J. P., Heat Transfer (Ninth edition), USA: McGraw-Hill Publishing Company Limited, 2002.

[8] Eastop, D. T. andMcConkey, A.,Applied thermodynamics for engineering technologists (Fifth Ed.), England: Pearson Education Limited, 1993.

[9] Ebadian, A.M and Lin,R.C.,Developing turbulent convective heat transfer in helical pipes, Int. J. Heat Mass Transfer 40: 3861-3873, 1997.

[10] Griffith J.F. and Barnard J.A.,Flame and combustion (Third $E d$.). Glasgow: Blackie A and P, 1995.

[11] Ho, J.C. andWijeysundera, N.E.,An unmixed-air flow model of a spiral cooling dehumidifying heat transfer, Appl. Therm. Eng. 19: 865-883,1999.

[12] Ho, J.C. andWijeysundera, N.E.,Study of a compact spiral-coil cooling and dehumidifying heat exchanger unit, Appl. Therm. Eng. 16:777-790, 1996.

[13] Kou, K.K.,Principle of combustion. U.S.A: John Wiley \& Sons, 1986.

[14] Laing, S.Y., Liu, M., Nathan, G.K., and T.N. Wong., Analytical study of evaporator coil in humid environment, Appl. Therm. Eng. 19: 1129-1145, 1999.

[15] Lemenand, T. and Peerhossaini,H., A thermal model for prediction of the Nusselt number in a pipe with chaotic flow, Appl. Therm. Eng. 22: 1717-1730, 2002.

[16] Lin, C.X. and Zheng, B.,Combined laminar forced convection and thermal radiation in helical pipe, Int. J. Heat Mass Transfer 43: 1067-1078, 2000.

[17] Naphon, P. andWongwises S., An experimental study on the in-tube heat convective heat transfer coefficients in a spiral-coil heat exchanger, Int. Comm. Heat Mass Transfer 29: 797-809, 2002.

[18] Naphon, P. andWongwises S., Experimental and theoretical investigation of the heat transfer characteristics and performance of a spiral-coil heat exchanger under dry-surface conditions, $2^{\text {nd }}$ International Conference on Heat Transfer, Fluid Mechanics, and Thermodynamics, 24-26 June, 2003, Victoria Falls, Zambia.

[19] Naphon, P. andWongwises, S., A study of the heat transfer characteristics of a compact spiral coil heat exchanger under wet-surface conditions, Experimental Thermal and Fluid Science 29: 511 - 521, 2005.
[20] Naphon, P. andWongwises, S., Heat transfer characteristics and performance of a spirally coiled heat exchanger under sensible cooling conditions, Japanese Society of Mechanical Engineers Int. J. SeriesB, 48: 810 - 818, 2005.

[21] Prabhanjan, D. G., Raghavan, G. S. V. and Rennie, J. T., Comparison of heat transfer rates between a straight tube heat exchanger and a helically coiled heat exchanger, Int. Comm. Heat Mass Transfer 29: 185-191, 2002.

[22] Rajput, R. K.,Heat and mass transfer (Third Ed.), India: RajendraRavindra Printers, 2007.

[23] Rajput, R. K.,Fluid mechanics and hydraulic machines. (Sixth Ed.), India: RajendraRavindra Printers, 2008.

[24] Rindt, C.C.M., Sillekens, J.J.M., and Van Steenhoven, A.A., Developing mixed convection in a coiled heat exchanger, Int. J. Heat Mass Transfer 41: 61-72, 1998.

[25] Rindt, C.C.M., Sillekens, J.J.M., and Van Steenhoven, A.A., The influence of the wall temperature on the development of heat transfer and secondary flow in a coiled heat exchanger, Int. Comm. Heat Mass Transfer 26 (1999) 187-198.

[26] Rogers, G. and Mayhew, Y.,Thermodynamic and transport properties of fluids (Second Ed.). Oxford: Basil Blackwell, 1972.

[27] Rogers, G. and Mayhew, Y.,Engineering thermodynamics: work and heat transfer (Fourth Ed.), India: Addison Wesley Longman (Singapore) Pte Ltd, 2001.

[28] Sieder, E. N. and Tate C. E.,Heat Transfer and Pressure Drop of Liquids in Tubes, Ind. Eng. Chem., vol. 28, p. 1429, 1936.

[29] Strehlo, R.A.,Combustion fundamentals, Singapore:McGraw Hill, 1984.

[30] Acharya, N. and Sen, M., Analysis of heat transfer enhancement in coiled-tube heat exchangers, Int. J. Heat Mas Transfer 44: 3189-3199, 2001.Bejan, A., Heat Transfer, USA: John Wiley and Sons, 1993.

[31] Boles, A.M. and Cengel A.Y.,Thermodynamics: an engineering approach (Third Ed.), U.S.A: McGraw - Hill, 1998.

[32] Bolinder, C.J. and Sunden, B., Numerical prediction of laminar flow and forced convective heat transfer in a helical square duct with finite pitch, Int. J. Heat Mass Transfer 39: 3101-3115, 1996.

[33] Cengel, Y. A.,Heat transfer: a practical approach (International Ed.), U.S.A: McGraw - Hill, 1998.

[34] Chandratilleke, T.T., Ho, J.C., Rajasekar S.,Wijeysundera, N.E., Performance of a compact spiral coil heat exchanger, Heat Recovery Syst. \& CHP 15: 457-468, 1995.

[35] Christensen, N.R., Garimella, S. and Richards, D.E., Experimental investigation of heat transfer in coiled annular ducts, J Heat Transfer 110: 329 - 336, 1988.

[36] Douglas, F. J., Gasiorek, M. J and Swaffield, A. J., Fluid mechanics (Fourth Ed.), India: Pearson Education (Singapore) Pte Ltd, 2002. 